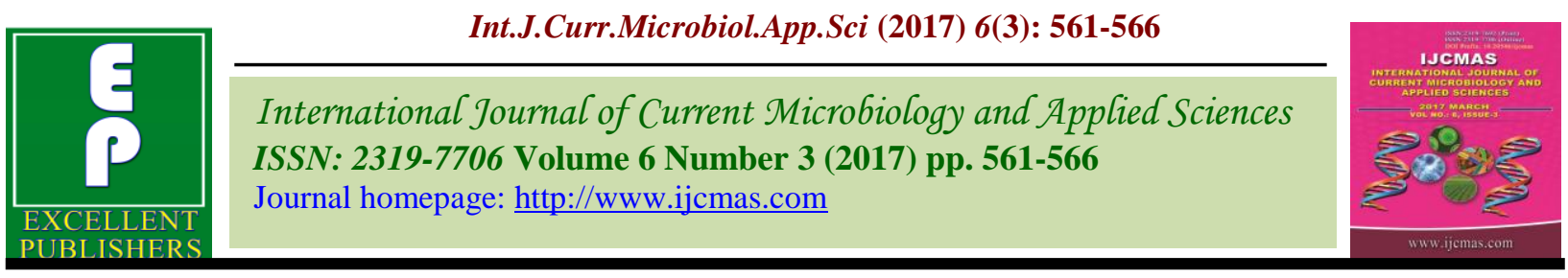

Original Research Article

https://doi.org/10.20546/ijcmas.2017.603.065

\title{
Black Pepper (Piper nigrum) Fruit Extract Activity against Some Pathogenic Bacterial Strains by Disc Diffusion Method
}

\author{
Alka Sahrawat ${ }^{1 *}$, Siddarth N. Rahul ${ }^{2}$ and Sushil Kumar Shahi ${ }^{1}$ \\ ${ }^{1}$ Department of Microbiology C.C.S. University Meerut 250110, India \\ ${ }^{2}$ Department of Plant pathology Sardar Vallabh Bhai Patel University of Agriculture and \\ Technology Modipuram, Meerut 250110, India \\ *Corresponding author
}

A B S T R A C T

Keywords

Antibacterial activity, MIC, Disc diffusion method.

Article Info

Accepted:

10 February 2017

Available Online:

10 March 2017

Antibacterial activities of Black pepper fruit extract were studied against some bacterial strains as- Pseudomonas fluorescens, Pseudomonas aeruginosa, Klebsiella pneumoniae, Proteus vulgaris, and Bacillus subtilis. The black pepper fruit extracts were prepared in four organic solvents as methanol, ethyl acetate, chloroform and benzene. Effectiveness against bacterial strains showed by all extract (which prepared by organic solvent) but the benzene extract showed the maximum growth inhibition $81.20 \%$ against Klebsiella pneumoniae bacteria at $100 \mu \mathrm{l} / \mathrm{ml}$ extract concentration. It is also resistance for some antibiotics as Lincomycin and Oleandomycin. The present study depict that the black pepper fruit extract showed good antibacterial activity.

\section{Introduction}

Medicinal plant is very important one in human health, it will act as an antibactericide activity against the bacterial pathogens, that is followed from ancient times (Zaikaa, 1988). Plant can serve as a source of innovation therapeutic agents against the infectious diseases (Singh, 2013). The natural products derived from medicinal plants have been used for years in traditional medicine to treat the different diseases and many of them possess antimicrobial activities (Vikas et al., 2012 and Pandey et al., 2012). According to estimate $80 \%$ population depends on plant derived products as medicine to meet the demands (Haq, 2004).
The plant extract and secondary metabolites possess antimicrobial, antifungal or antiviral activities. The various plants products that are regularly used for their therapeutic potential and plants or plants products, that form the part of the food or as dietary components, has been receiving considerable attention. Though much is known about the chemistry and the antimicrobial action of several phytochemical, very few reports are available on the phenolic compound an injury of membrane functions has been proposed as a mechanism of action (Aizenman, 1978; Mitscher, 1978; Sashidhar, 2002; Davidson and Branen, 1981). The term spices refer to aromatic pungent vegetable 
substances used for flavouring foods and have several commercial uses according to (ISO). Since ancient times people used spices for preventing food and deterioration and pathogenic diseases. Spices have become today as an integral part of our daily diet and many of the spices are widely used to flavour food and beverages, for food preservation, medicinal preparations, cosmetics, perfumery, bakery goods, and various other products. Even today spices are used as an ingredient in drug preparation in Unani, Homeopathy and Ayurveda system of medicine. Phytochemical investigation of the aerial part of the plants and Tartaric acid, Acetic acid, Citric acid, Succinic acid, Gums, Pectin, Sugar, Tannins, Alkaloid, Flavonids, Glycosides and Sesquiterpens (Chopra, 1958; Algohary, 1994; Mohamedan, 1996; Aida, 2001).

Black paper is known as the "King of Spices", the oldest and the highly valuable medicinal spice in India. The spicy tang of black pepper is due it's important and well researched phytochemical, pipenine (Madhuri, 2009). Black pepper (Piper nigrum) is a flowering vine of the Piperaceae family that is cultivated for its fruit, which is usually dried and used as a spice and seasoning. In dried form the fruit is referred to as peppercorns. It is native of south India and popularly known as "King of Spices" (Algohary et al., 1994; Chiranjib et al., 1990; Ali, 1995; Park, 2004). Black pepper is also used for different purpose such as human dietaries as medicine, as preservatives, as biocontrol agent (Awen, 2010 \& Hussain, 2011). Pepper is most commonly used in curry recipes, as masala and also included in the prescriptions of ayurveda and other traditional medicinal system. Pepper is also used in folk medicine as aphrodisiac (Algohary, 1994; Chiranjib 1990; Ali, 1995; Park et al., 2004). The present study was carried out to determine the activity of methanol, ethyl acetate, chloroform and benzene extract of black pepper (Piper nigrum) fruit against Pseudomonas fluorescens, Pseudomonas aeruginosa, Klebsiella pneumoniae, Proteus vulgaris, and Bacillus subtilis which are pathogenic and antibiotic resistance.

\section{Materials and Methods}

\section{Preparation of plant material}

The plant material (fruit part) was collected from the cotton research station D.M. road Bulandshahr region UP (India) during February 2013. Collected plant material was clean up and crushed into powder form using pistal mortal.

\section{Extract preparation}

Fruit extract were prepared by immersing $1 \mathrm{gm}$ of powder in $5 \mathrm{ml}$ with four different organic solvents as Methanol, Ethyl acetate, Chloroform and Benzene for 24 hours after filtration the extract were evaporated by the help of rotator evaporator. For stock solution each extract was re-dissolved with $5 \mathrm{ml}$ DMSO (dimethyl sulphoxide).

\section{Test Microbial Strains}

All tested bacterial strains viz Pseudomonas aeruginosa (MTCC 162), Pseudomonas fluorescens (MTCC 254), Proteus vulgaris (MTCC 123), Bacillus subtilis (MTCC 251), Klebsiella pneumoniae (MTCC 140) were collected from MTCC (microbial type culture collection) IMTECH Chandigarh. These microorganism were maintained on nutrient agar media (NAM) at $30^{\circ} \mathrm{C}$ for further investigation

\section{Antibacterial screening of Black pepper (Piper nigrum) fruit extracts against test pathogens}

The antimicrobial screening of the bacterial strains were carried out disc diffusion method (Grover and Moore, 1962). The plant extracts 
of $0.1 \mathrm{ml}$ were mixed in $0.9 \mathrm{ml}$ of pre sterilized nutrient broth and then added $0.1 \mathrm{ml}$ bacterial culture suspension. In control sets, DMSO (in place of the plant extract) was used in the medium in appropriate amount. Culture tube were incubated for 24 hours at $30^{\circ} \mathrm{C}$

After incubation, sterile disc of $6 \mathrm{~mm}$ (Hi media) were dip in to the broth (treated as well as control separately), disc were aseptically inoculated on the agar surface of the nutrient agar medium in plates. Inoculated petriplates were incubated at $30^{\circ} \mathrm{C}$ and the observations were recorded after 24 hours. Percentage of bacterial growth inhibition (BGI \%) was calculated per formula.

BGI $(\%)=$ - $\mathrm{dc}$ dt

where, $\mathrm{dc}=$ diameter of control

$\mathrm{dt}=$ diameter of test

\section{Determination of MIC of extracts by Micro titer plates assay}

MIC (mininmum inhibitory concentration) expressed as the lowest dilution, which inhibited growth judge by the lack of turbidity in the tube. A broth micro dilution assay was adopted using 96 well micro titter plates with resazurin. It was carried out to assess the microbial growth and determination the minimal inhibitory concentration (Sarker, et $a l .$, 2007). The resazurin (oxidation- reduction indicator) solution was prepared by dissolving a 270mg tablet in $40 \mathrm{ml}$ of sterile distilled water. A sterile 96 well micro titter plates was taken for the test. 50 $\mu 1$ of test extract were pipette in to first row of the micro titter plate A1 well to $\mathrm{A} 2$ to $\mathrm{H} 2$ till $\mathrm{A} 12$ to $\mathrm{H} 12$ were dispensed with $50 \mu 1$ of nutrient broth. $50 \mu 1$ of test extract was transferred from test solution (A1-H1) to next wells (A2-H2) and so on to create serial dilution. $30 \mu \mathrm{l}$ of the test culture were mixed in serially descending concentration to each well from A2 to $\mathrm{H} 2$ till A12 to H12. In last $20 \mu 1$ of resazurin solution was added in all tested as well as control set. A11, A12 and H11, H12 served as control set. $50 \mu 1$ of DMSO was used in place of extracts. The plates were incubated at $30^{\circ} \mathrm{C}$ for 24 hours. The colour change was then assessed visually. Any colour changes from purple to pink or colorless were recorded as positive. The lowest concentration at which colour change occurred was taken as the MIC value. The average of two values was calculated.

\section{Results and Discussion}

Some bacterial strains were drug resistance for some antibiotic viz klebsiella pneumoniae was resistance for many drugs as lincomycin and oleandomycin (Table 1) The result of antibacterial activity of Black pepper (Piper nigrum) fruit was determined by disc diffusion method. All the extract of black pepper showed the antibacterial activity against all the pathogenic bacterial strains. The Methanol extract of Piper nigrum fruit showed maximum growth inhibition $61.65 \%$ against Klebsiella pneumoniae and also showed minimum growth inhibition $1.85 \%$ against Pseudomonas fluorescens. The Ethyl acetate extract of Piper nigrum fruit showed maximum growth inhibition $80.04 \%$ against Klebsiella pneumoniae and also showed minimum growth inhibition $0 \%$ against Proteus vulgaris.

The Chloroform extract of Piper nigrum fruit showed maximum growth inhibition $69.17 \%$ against Klebsiella pneumoniae and also showed minimum growth inhibition $-1.85 \%$ against Pseudomonas fluorescens. The Benzene extract of Piper nigrum fruit showed maximum growth inhibition $81.20 \%$ against Klebsiella pneumoniae and also showed minimum growth inhibition $-32.03 \%$ against Pseudomonas aeruginosa (Table 2). 
Table.1 Zone of inhibition by different drugs against bacterial strains (Sahrawat and Shahi, 2013)

\begin{tabular}{|l|l|l|l|}
\hline Antibiotics & \multicolumn{3}{|c|}{ Zone of drug against bacterial strains (mm) } \\
\hline & Proteus vulgaris & $\begin{array}{l}\text { Pseudomonas } \\
\text { fluorescens }\end{array}$ & $\begin{array}{l}\text { Klebsiella } \\
\text { pneumoniae }\end{array}$ \\
\hline Tabramycin & 21 & - & 23 \\
\hline Cephaloridine & 17.5 & - & 14.5 \\
\hline Kanamycin & 22.5 & 11.5 & 12.5 \\
\hline Lincomycin & - & - & - \\
\hline Norfloxacin & 13 & - & 18.5 \\
\hline Oleandomycin & - & - & - \\
\hline
\end{tabular}

Table.2 Antibacterial screening of different extract of Piper nigrum against pathogenic bacterial strains by Disc diffusion method

\begin{tabular}{|c|c|c|c|c|}
\hline \multirow{2}{*}{ Pathogens } & \multicolumn{4}{|c|}{ Percentage of growth inhibition at 100ul/ml } \\
\cline { 2 - 5 } & Methanol & Ethyl acetate & Chloroform & Benzene \\
\hline $\begin{array}{c}\text { Pseudomonas } \\
\text { aeruginosa }\end{array}$ & $41.17 \%$ & $48.52 \%$ & $52.94 \%$ & $-32.03 \%$ \\
\hline $\begin{array}{c}\text { Pseudomonas } \\
\text { fluorescens }\end{array}$ & $1.85 \%$ & $25.92 \%$ & $-1.85 \%$ & $40.74 \%$ \\
\hline Bacillus subtilis & $42.15 \%$ & $62.74 \%$ & $52.94 \%$ & $67.64 \%$ \\
\hline Proteus vulguris & $25.07 \%$ & $0 \%$ & $27.27 \%$ & $-28.07 \%$ \\
\hline $\begin{array}{c}\text { Klebsiella } \\
\text { pneumoniae }\end{array}$ & $61.65 \%$ & $80.04 \%$ & $69.17 \%$ & $81.20 \%$ \\
\hline
\end{tabular}

Table.3 Minimum inhibitory concentration of Piper nigrum fruit against bacterial strains

\begin{tabular}{|l|l|l|l|l|}
\hline \multirow{2}{*}{ Bacterial strains } & \multicolumn{4}{|c|}{ MIC against pathogens in $\boldsymbol{\mu l} / \mathbf{m l}$} \\
\cline { 2 - 5 } & Methanol & Ethyl acetate & Chloroform & Benzene \\
\hline $\begin{array}{l}\text { Klebsiella } \\
\text { pneumoniae }\end{array}$ & $1.56 \times 10^{-6}$ & $6.25 \times 10^{-4}$ & $3.12 \times 10^{-5}$ & $12.5 \times 10^{-3}$ \\
\hline
\end{tabular}

Fig.1 Effect of different extracts on bacterial growth

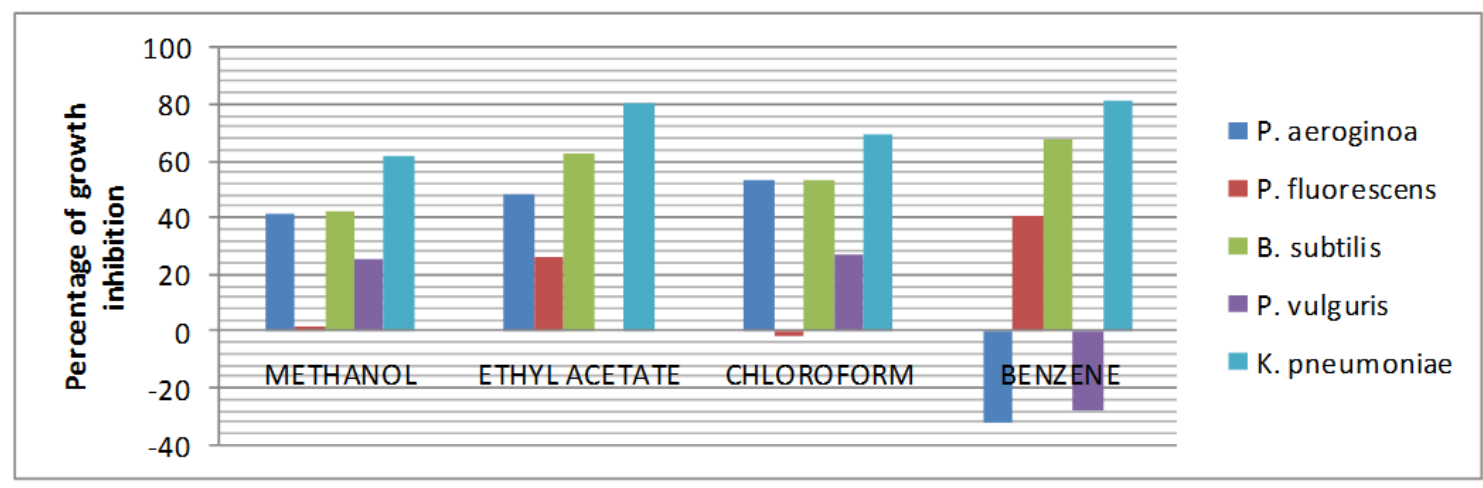


The MIC value of Methanol extract against Klebsiella pneumoniae was $1.56 \times 10^{-6} \mu \mathrm{l} / \mathrm{ml}$, in Ethyl acetate extract against Klebsiella pneumoniae was $6.25 \times 10^{-4} \mu \mathrm{l} / \mathrm{ml}$, in Chloroform extract against Klebsiella pneumoniae was $3.12 \times 10^{-5} \mu \mathrm{l} / \mathrm{ml}$, in Benzene extract against $12.5 \times 10^{-3} \mu 1 / \mathrm{ml}$ (Table 3). Piper nigrum, commonly known as black pepper in Indian spice. Spices we used in our daily diet can provide protection towards the bacteria and fungi (Shiva et al., 2013) (Fig. 1).

The spicy tang of pepper is due to the presence of piperamides which are the pungent bioactive alkaloids accumulates in the skin and seed of the fruit (Friedman et al., 2008). According to alkaloid plays a significant role in plant physiology, agriculture, host-plant resistance, entomology, the diet and medicine. Among them piperine is the major chemical constituent responsible for the bitter taste of the black pepper. It has been found that $p$. nigrum leaf extract inhibits the growth of bacterial strains (Larhsini et al., 2001; Sasidhran and Menon, 2010). According to the study not only the black pepper fruit part show the effectiveness but also every part show the effectiveness of numerous health related effects such as antibacterial, antifungal, and anticarcinogenic, antithrombicand vasodilator activities (Bidlack et al., 2000). The fruit contain 1\% volatile oil, resin, a waxy alkaloid, used for several medicinal properties (Atal et al., 1985). In our study the benzene extract of Piper nigrum showed maximum antibacterial activity against tested bacterial strains.

\section{References}

Aizenman, B.E. 1978. Higher plant as a source for the preparation of new antibiotic, microbial zh (kiev) 40: 233241.

Algohary, M.E.M., Mahmoud, B.M., Ali, H.M. and Homeida, M.M 1994.
Medicinal plants of North Africa, pp, 142-144.

Aida P.V., Posa, V., Blamea, F., Tomas, A. and Salvador, C. 2001. Paraguyan plants used in traditional medicine. $J$. Ethanopharmacol, 16: 93-98.

Ali, W.E.M.M. 1995. Toxicological study on medicinal plants piper Abyssinica and Indigifera oblongifolia. Ph.d thesis, university of Khartoum, Sudan.

Awen, B.Z., Ganpati, S. and Chandu, B.R. 2010. Influence of Sapindus mukorossi on the permeability of ethyl cellulose free film for transedermal use. Res. J. Pharma Bio Sci., 7: 35-38.

Atal, C.K., A.K. Dubey and Singh, J. 1985. Biochemical basis of enhanced drug availability of piperine, J. Exp. Ther., 232: 258-262.

Bidlack, W.R., S.T. Omaye, M.S. Meskin and Topham, D.K. 2000. Phytochemicals as bioactive agents. CRC press, boca raton, fl.

Chopra, R.N., S.L Nayar and chpora I.C. 1958. Glossary of Indian medicinal plants, CSIR new delhi

Chiranjib, B., B.S. Narayan, P.S. Variyar and Bandyopadhya, C. 1990. Phenolics of green pepper berries (Piper nigrum) $J$. Agri. Food Chem., 38: 8-12.

Davidson, P.M. and Branen, A.L. 1981. Antimicrobial activity of non halogenated phenolic compound. $J$ Food Prot., 44: 623-632.

Friedman, M., Levin, C.E., Seung-un Lee, Jin-shik Lee, Mayumi ohnisi-kameyama and Kozukue, N. 2008. Analysis by HPLC and $1 \mathrm{c} / \mathrm{mc}$ of pungent piperamides in commercial black, white, green and red whole and ground peppercorns. J. Agric. Food Chem., 56: 3028-3036.

Grover, R.K. and Moore, J.D. 1962. Toximetric studies of fungicides against brown rot organism. Sclerotina fruticola. Phytopathol., 52: 876-880. 
Haq, I. 2004. Safety of medicinal plant. Pak. J. Med. Res., 43(4): 153- 156

Hussain, A., S. Naz, H. Nazir, and Shinwari, Z.K. 2011. Tissue culture of black pepper (Piper nigrum) in Pakistan. Pak. J. Bot., 43: 1069-10

Larhsini, M., L. Oumoulid, H.B. Larze, K., Bekkoiche and Jana, M. 2001. antimicrobial activity of some Moroccan medicinal plants. Phytother. Res., 15: 250-252.

Mitscher, L.A. 1978. Plant derived antibiotics. J. Chromaotogr. Libr., 15: 463-477.

Mohamedan, K.M., O.S.A. Mohamed, S.M.A. Elbadwi, and Adam, S.E.I. 1996. Effect of feeding Tamarindus indica ripe fruit in brown hisex chicks, Phytother. Res., 10: 631-634.

Madhuri, S. and Pandey, G. 2009. Some anticancer medicinal plants of foreign origin, Curr Sci., 96: 779-783.

Pandey, M., D.Sony, M.K. Viyas, S. Gupta, A. Singh, P. Shah, et al. 2012. Antibacterial evalution of plant extract, as insight into Phytomedicine. Int. J. Phytomed., 4(1): 6-11.

Park, J.E., H.J. Choi, S.H. Jung, N.J. Kim and Kim, D.H. 2004. East-west medicinal plant of korea, J. Pharmacogn., 32: 257-268

Singh, S.K. 2013. Antibacterial activity of different extract of Moringa oleifera leaf against some pathogenic bacteria. $J$. Pharm. Sci. Innov., 2(2): 13-15.
Sashidhar, N.S. 2002. Studies on bioactive compound for their antimicrobial and antioxidant properties. Ph.d thesis, submitted to Osmania university, Hydrabad india.

Sarkar, S.D., L. Nahar, and Kumarasamy. 2007. Microtitter plate based antibacterial assay incorporating resazurin as an indicator of cell growth, and its application in vitro antibacterial screening and phytchemical. Method, 42(4): 321-324.

Shiva, S.K. Rani, N. Saxena, and Udaysree. 2013. Antimicrobial activity of black pepper (Piper nigrum L.), Global J. Pharmacol., 7(1): 87-89.

Sasidhran, I. and Menon, A.N. 2010. Comparative chemical composition and antimicrobial activity of berry and leaf essential oil of Piper nigrum L. Int J. Boil.Med. Res., 4: 215-218.

Sahrawat, A. and Shahi M.P. 2013. Antibacterial screening of Sapindus mukorossi geartn fruit and Daucus carota L. root extract against pathogenic bacterial strains. Curr. Discovery, 2(1): 76-80.

Vikas, K., P. Nishtha, M. Nitin, and Ram, P.S. 2012. Antibacterial and antioxidant activity of different extract of Moringa oleifera leaves -an invitro study. Int. J. Pharma Sci.. Rev. Res., 12(1): 89-94.

Zaikaa, L.L. 1988. Spices and herbs. Their antimicrobial activity and its determination. J. Food. Safety, 9: 97118.

\section{How to cite this article: $s$}

Alka Sahrawat, Siddarth N. Rahul and Sushil Kumar Shahi. 2017. Black Pepper (Piper nigrum) Fruit Extract Activity against Some Pathogenic Bacterial Strains by Disc Diffusion Method. Int.J.Curr.Microbiol.App.Sci. 6(3): 561-566. doi: https://doi.org/10.20546/ijcmas.2017.603.065 